\title{
PATOGENISITAS JAMUR KARAT (PUCCINIA PHILIPPINENSIS Syd.), PADA GULMA TEKI (CYPERUS ROTUNDUS L.)
}

\author{
M.T. Fauzi ${ }^{1}$
}

\begin{abstract}
The pathogenicity of a rust fungus (Puccinia philippinensis Syd.), on purple nutsedges (Cyperus rotundus L.). A research aimed at understanding the pathogenicity of a rust fungus (Puccinia philippinensis Syd.), a potential biological control agent of purple nutsedges (Cyperus rotundus L.) had been conducted in a glasshouse of Faculty of Agriculture the University of Mataram. These factorial experiments designed according to Randomized Completely Design (CRD) and consisted of spore density and time of application. Spore density treatments consisted of 0, 5000, $10000,15000,20000,25000$, or 30000 spore/ $\mathrm{mL}$ applied either in the morning or in the afternoon. The results showed that the higher the spore density, the higher the number of pustules formed, the higher the disese intensity, and the faster the disease progressed. Urediniospores applied in the afternoon produced more pustules, higher disease intensity, and faster disease progression compare to those applied in the morning.
\end{abstract}

Key words: Puccinia philippinensis Syd., biological control of weeds, Cyperus rotundus L.

\section{PENDAHULUAN}

Teki (Cyperus rotundus L.) merupakan tumbuhan pengganggu yang dapat secara serius mengancam keberhasilan tanaman budidaya, karena keberadaannya di setiap tempat di daerah kering, potensi perkembangbiakannya dan kemampuannya yang sangat kuat dalam berkompetisi serta sulitnya dikendalikan baik secara mekanik maupun kimiawi jika telah tumbuh dengan baik. Pengendalian gulma teki dengan cara penyiangan (terutama dengan pembabatan) keberhasilannya akan sangat kecil, karena cukup banyaknya umbi-umbi yang terdapat di dalam tanah yang akan segera tumbuh dengan cepat membentuk tumbuhan baru (Pons et al., 1987). Sementara itu pengendalian secara kimia dengan menggunakan herbisida masih belum umum dilakukan di pulau Lombok untuk mengendalikan gulma teki. Konstermans et al. (1987), melaporkan bahwa penggunaan campuran $0,9 \mathrm{~kg}$ MSMA; 0,45 kg 2,4-D; 0,61 1 surfaktan dalam $90 \mathrm{~L}$ air yang diaplikasikan 5-6 kali dan glyphosate dapat menekan gulma ini. Akan tetapi penggunaan herbisida yang berkali-kali tersebut akan membutuhkan biaya yang cukup besar, selain dapat menimbulkan efek samping negatif pada lingkungan. Selain itu, pengendalian gulma teki dengan herbisida jarang berhasil dengan baik, terutama jika terdapat umbi-umbi dorman yang biasanya tahan terhadap herbisida, yang dapat tumbuh kembali dengan cepat. Oleh karena itu, pengendalian dengan kombinasi berbagai perlakuan seperti cara bercocok tanam, penggunaan herbisida, penyiangan dan pengendalian hayati (biologi) perlu diterapkan.

Pengendalian gulma secara hayati (biokontrol gulma) adalah penggunaan musuh-musuh alami (organisme hidup) selain manusia untuk mengurangi populasi gulma (Watson, 1991). Biokontrol gulma, terutama dengan menggunakan jamur-jamur patogen, akhir-akhir ini mendapat perhatian yang serius dari peneliti-peneliti di negara maju, karena selain cukup mempan sebagaimana pengendalian secara kimia juga mempunyai efek samping yang sangat kecil terhadap lingkungan. Salah satu jamur patogen gulma adalah jamur karat (Uredinales). Jamur karat merupakan kandidat bahan biokontrol yang mempunyai prospek yang baik untuk mengendalikan gulma, karena mampu menyebabkan kerusakan yang berat dan mempunyai inang yang sangat spesifik (Evans, 1995).

Di pulau Lombok, secara alami gulma teki terinfeksi oleh jamur karat Puccinia philippinensis Syd. Akibat infeksi ini pertumbuhan gulma teki menjadi terhambat, bahkan pada infeksi yang berat dapat menyebabkan pertumbuhan gulma teki sangat merana yang ditandai dengan daunnya yang berwarna coklat kehitam-hitaman. Sehingga jamur karat lokal ini

\footnotetext{
${ }^{1}$ Jurusan Budidaya Pertanian Fakultas Pertanian Universitas Mataram, J1. Pendidikan 37 Mataram 83125 NTB. Telp. (0370)640744 Fax. (0370) 640189. E-mail: taufikfz@telkom. net
} 
berpotensi untuk dikembangkan sebagai agen pengendali hayati gulma teki.

Pengembangan dan penerapan jamur karat P. phillipinensis ini dilakukan dengan cara augmentasi, yakni patogen yang digunakan merupakan patogen yang diperoleh di tempat gulma tersebut menjadi masalah, tetapi tidak dapat diformulasikan karena patogen yang digunakan bersifat obligat parasit dan penerapannya dilakukan dengan melepaskan spora dalam jumlah yang banyak dan pada saat yang kondusif bagi perkembangan jamur karat tersebut (Charudattan, 1985; Phatak et al., 1983). Misalnya, jamur karat $P$. canaliculata yang ditemukan menyerang gulma 'teki kuning' di Amerika Serikat telah dikembangkan untuk mengendalikan gulma tersebut dengan pendekatan augmentasi (Evans, 1991). P. canaliculata ini jika diterapkan pada saat yang tepat (keadaan yang kondusif bagi perkembangan jamur) dan dalam jumlah yang memadai mampu menghambat pembungaan dan pembentukan umbi gulma tersebut (Callaway et al., 1985; Phatak et al., 1983; TeBeest et al., 1992). Sehingga, pengembangan jamur karat P. phillipinensis lokal yang menginfeksi gulma teki di pulau Lombok akan mempunyai peluang yang sama atau bahkan lebih besar dalam mengendalikan gulma teki terutama untuk daerah tropik.

Penelitian ini bertujuan untuk mengetahui patogenisitas jamur karat lokal Lombok pada gulma teki. Untuk itu telah dilakukan penelitian tentang waktu aplikasi dan jumlah inokulum jamur karat (Puccinia philippinensis Syd.) lokal lombok yang diterapkan secara augmentasi untuk mengendalikan gulma teki (Cyperus rotundus L.) untuk melihat potensinya sebagai agen pengendali hayati dari gulma tersebut.

\section{METODE PENELITIAN}

Penelitian ini merupakan ekperimental murni yang dilaksanakan di Rumah Plastik dan Laboratorium Proteksi Fakultas Pertanian, Universitas Mataram, pada bulan Agustus sampai bulan November 2004.

Koleksi spora. Sebelum percobaan dimulai, jamur karat dikoleksi dari hamparan gulma teki terinfeksi di Mataram, Lombok. Koleksi dilakukan dengan mengerik spora dari daun terinfeksi menggunakan kuas halus dan spora yang jatuh ditampung dengan kertas aluminium (agar tidak melekat) dan dimasukkan dalam vial-vial plastik. Spora terkoleksi ini kemudian ditaruh dikontainer yang terdapat silica gel di dalamnya, sebelum inokulasi dilakukan.
Penyiapan tanaman, spora dan inokulasi. Teki yang berasal dari umbi ditumbuhkan pada pot-pot berdiameter $15 \mathrm{~cm}$ yang sebelumnya telah diisi dengan tanah yang dicampur dengan pasir (3:1), dengan setiap pot berisi satu tanaman. Sebelum inokulasi, dilakukan persiapan suspensi spora. Spora yang dikoleksi tersebut dicampur dengan larutan aquadest steril dan ditambahkan 0,2\% perekat dan perata Lybsorb (Greenter ${ }^{\circledR}$ ). Gulma teki yang sebelumnya telah ditumbuhkan diinokulasi dengan mengunakan hand sprayer dengan spora yang dikoleksi dari pustul-pustul berumur 15 hari dengan kepadatan spora bervariasi mulai dari 0 sampai dengan 30.000 spora/ml. Inokulasi dilakukan dengan menyemprotkan larutan ke bagian bawah daun sebanyak 5 kali. Setelah inokulasi polibag disungkup dengan plastik hitam yang sebelumnya telah dibasahi bagian dalamnya dengan air untuk memberikan lingkungan berkelembaban tinggi. Setelah 24 jam plastik penutup tersebut dibuka.

Rancangan percobaan. Percobaan dirancang dengan Rancangan Acak Lengkap yang terdiri dari dua faktor yaitu kerapatan spora dan waktu aplikasi. Kerapatan spora yang digunakan berturut-turut: $0,5000,10.000$, 15.000, 20.000, 25.000, atau $30.000 \mathrm{spora} / \mathrm{ml}$ larutan; dan waktu aplikasi pagi hari (Pukul 07.00 WITA) atau sore hari (Pukul 17.00 WITA). Masing-masing perlakuan diulang sebanyak tiga kali.

Peubah yang diamati meliputi saat timbulnya gejala, jumlah pustul yang timbul setelah timbulnya gejala pertama yang diamati setiap hari sampai pustul yang terbentuk tidak bisa dihitung lagi karena terjadi penggabungan antara pustul atau tidak ada lagi pustul yang terbentuk, dan intensitas penyakit. Intensitas penyakit ditentukan dengan pendekatan berat pustul yang terdapat pada daun yang terinfeksi. Hal ini dilakukan dengan memotong bagian daun yang terinfeksi kemudian ditimbang. Perhitungan intensitas penyakit dengan rumus sebagai berikut :

$$
I P=\frac{a}{b} \times 100 \%
$$

$$
\begin{aligned}
& \text { Keterangan: } \\
& \text { IP = Intensitas Penyakit } \\
& \mathrm{a}=\text { Berat pustul } \\
& \mathrm{b}=\text { Berat tanaman }
\end{aligned}
$$

Selain itu juga diamati perkembangan penyakit yang dianalisis berdasarkan luas area yang terbentuk dari grafik pengamatan jumlah pustul dengan interval 
waktu tertentu (dengan menghitung 'area under the disease progress curve' = AUDPC) $($ Campbell \& Madden, 1990). Hasil variabel yang diamati dianalisis dengan mengunakan Analisis Sidik Ragam (Steel \& Torrie, 1981), dan jika terdapat adanya perbedaan variasi di antara perlakuan atau kombinasi perlakuan maka dilanjutkan dengan uji BNT pada taraf 5\%. Hubungan antara kerapatan spora dan jumlah pustul yang terbentuk dan intensitas penyakit dianalisis menggunakan analisis regresi.

\section{HASIL DAN PEMBAHASAN}

Hasil penelitian menunjukkan bahwa jamur Puccinia philippinensis, yang diinokulasikan bersifat patogenik (dapat menimbulkan penyakit) pada gulma teki yang ditandai dengan gejala penyakit yang ditimbulkannya yaitu pada awalnya berwarna kekuningkuningan, kemudian setelah beberapa hari terbentuk pustul yang berwarna coklat kemerah-merahan pada bagian bawah daun gulma teki serta pada perkembangan selanjutnya pustul tersebut membesar dan berubah warna menjadi coklat kehitam-hitaman.

Kerapatan spora, waktu aplikasi dan interaksi antara keduanya tidak berpengaruh nyata terhadap saat timbulnya gejala pertama (masa inkubasi). Masa inkubasi yang paling cepat adalah 7 hari yang terjadi pada hampir semua perlakuan. Masa inkubasi yang paling lambat adalah 13 hari yang terjadi pada perlakuan kepadatan spora terendah yang diinokulasikan pada pagi hari. Timbulnya penyakit atau gejala tergantung pada interaksi antara patogen dan tanaman inang. Bila tanaman inang yang rentan berinteraksi dengan patogen yang virulen akan mengakibatkan gejala muncul lebih awal. Sebaliknya bila tanaman inang resisten berinteraksi dengan patogen yang virulen maka akan mengakibatkan munculnya gejala akan lebih lama. Namun untuk timbulnya suatu penyakit atau keberhasilan interaksi antara patogen dan inang untuk timbulnya penyakit harus didukung oleh faktor lingkungan. Kondisi lingkungan yang mendukung terjadinya penyakit terutama adalah suhu dan kebasahan daun (kelembaban) pada saat inokulasi, sebagaimana dilaporkan oleh Fauzi et al. (1996; 1999) bahwa suhu dan kebasahan daun sangat penting terhadap terjadinya infeksi dan perkembangan jamur karat $P$. abrupta var. partheniicola (PAP) bahan biokontrol gulma partheniun di Australia. Bilamana kedua kondisi lingkungan menguntungkan bagi patogen maka tingkat virulensi patogen dapat meningkat sehingga gejala dapat muncul lebih awal.

Hubungan antara kerapatan spora dan jumlah pustul yang terbentuk pada masing-masing waktu

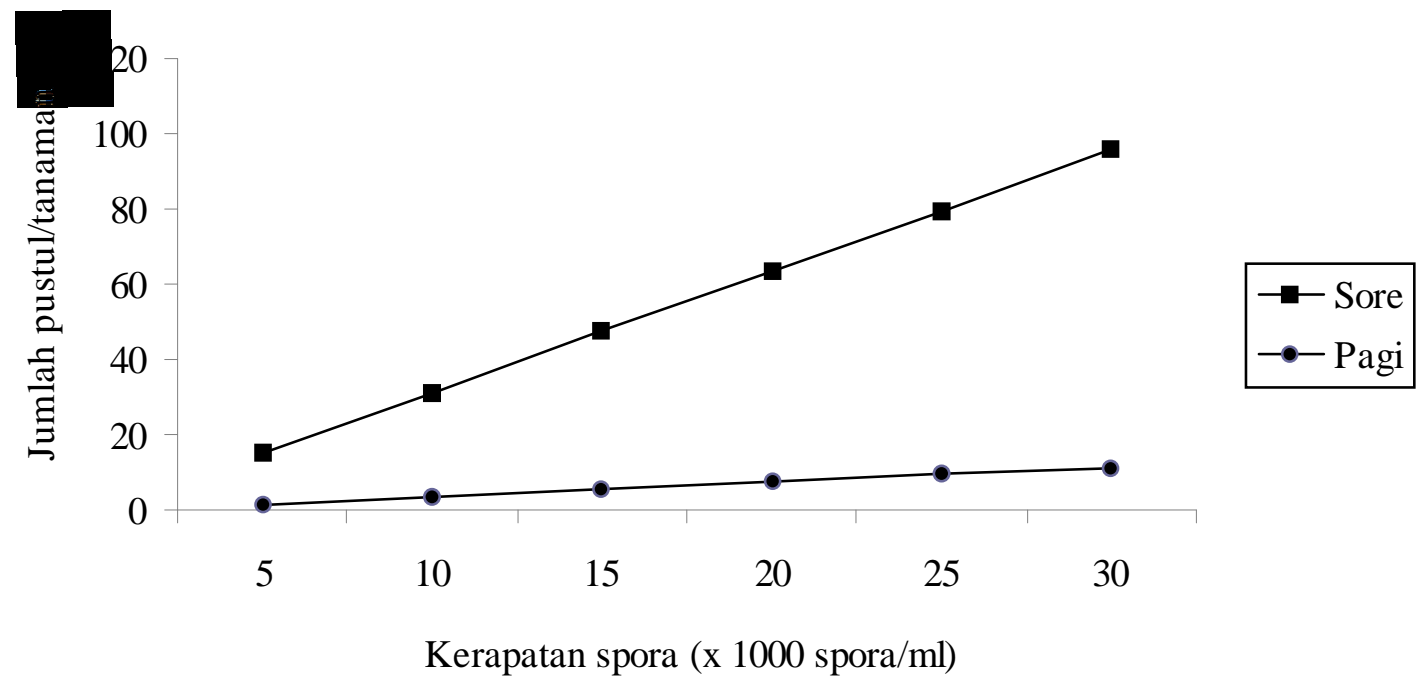

Gambar 1. Pengaruh kerapatan spora dan waktu aplikasi terhadap jumlah pustul yang terbentuk pada gulma teki 
aplikasi dapat dilihat pada Gambar 1.

Gambar 1 menunjukkan bahwa jumlah pustul yang terbentuk paling sedikit terdapat pada kerapatan spora terendah $(5000 \mathrm{spora} / \mathrm{ml})$ dan jumlah pustul paling banyak terdapat pada kerapatan spora tertinggi (30.000 spora/ $\mathrm{ml})$. Semakin tinggi kerapatan spora maka jumlah pustul yang terbentuk juga semakin banyak. Nilai b (koefesien regresi) pada waktu inokulasi sore hari lebih besar dibandingkan waktu inokulasi pagi hari (Tabel 1), yang menunjukkan bahwa jumlah pustul yang terbentuk pada waktu inokulasi sore hari lebih banyak dibandingkan dengan waktu inokulasi pagi hari. Jumlah pustul yang terbentuk pada konsentrasi paling rendah yang diinokulasikan sore hari lebih banyak dibandingkan dengan jumlah pustul yang terbentuk pada konsentrasi paling tinggi yang diinokulasikan pagi hari.

Gambar 1 menunjukkan bahwa jumlah pustul yang terbentuk semakin banyak dengan semakin meningkatnya kerapatan spora. Pada tingkat kerapatan spora (urediniospora) yang diinokulasikan tinggi, jumlah urediniospora yang kontak dengan gulma teki akan semakin b berkecamba bah yang selanjutnya ngan daun gulma teki, s diniospora dan jaringar ngkungan mendukung ngadakan

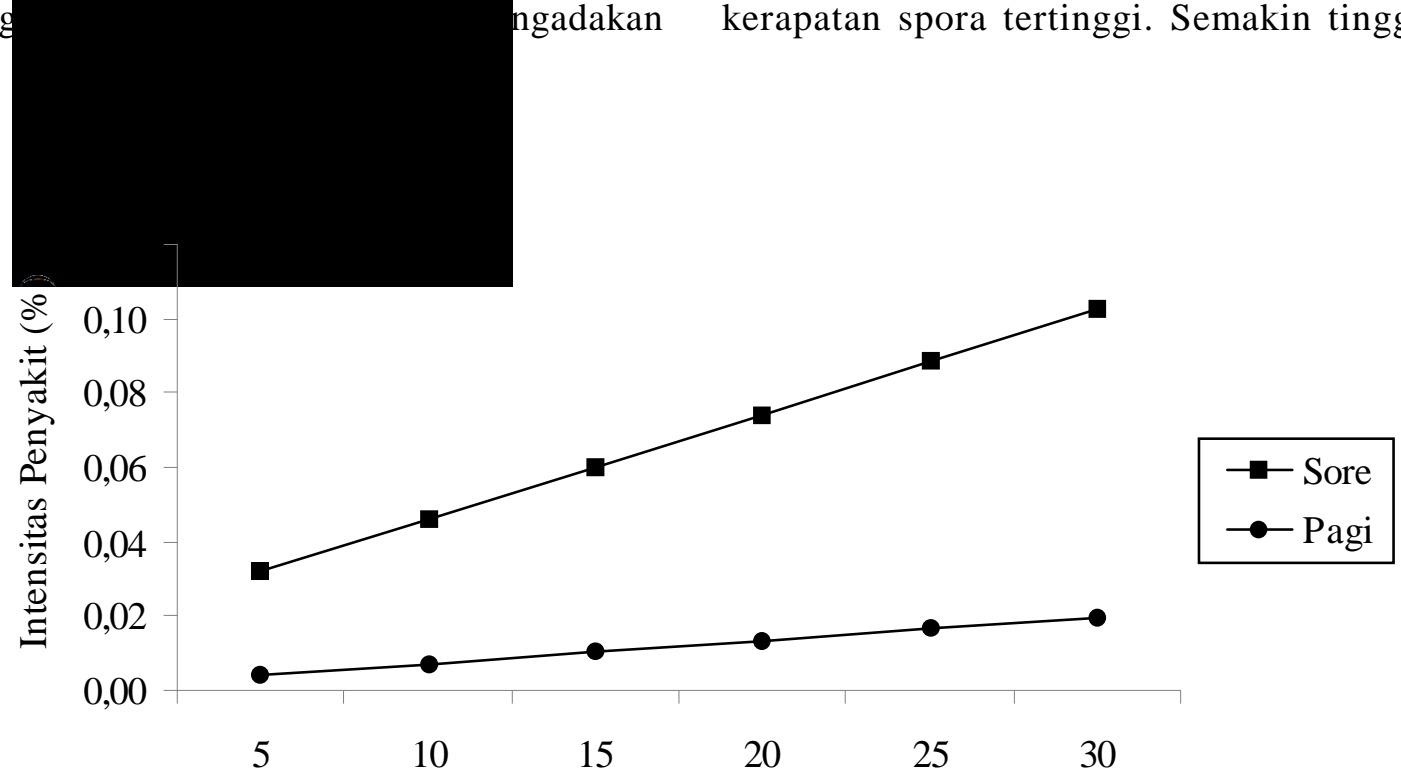

Kerapatan Spora (x 1000) interaksi dengan jaringan daun gulma teki (inang) ini akan menimbulkan gejala (penyakit). Oleh karena itu, pada kondisi urediniospora yang banyak berinteraksi dengan jaringan gulma teki maka jumlah pustul (gejala) akan semakin banyak pula. Akibatnya dengan semakin banyaknya jumlah pustul yang terbentuk maka berat pustul juga semakin besar sehingga intensitas penyakit yang dihasilkan juga tinggi. Hal ini didukung oleh pendapat Sirjusingh et al. (1996) yang menyatakan bahwa insiden Botrytis cinerea yang menyerang tumbuhan geranium meningkat dengan semakin meningkatnya kerapatan konidia. Nutman \& Roberts (1963) juga melaporkan bahwa gejala semakin banyak dengan semakin meningkatnya inokulum jamur karat Hemileia vastatrix yang menyerang tanaman kopi. Sebaliknya bila jumlah urediniospora yang berinteraksi dengan jaringan gulma teki sedikit maka jumlah pustul (gejala) yang terbentuk juga akan semakin sedikit, sehingga bobot pustul juga rendah, akibatnya intensitas penyakit yang dihasilkan juga rendah.

Hubungan antara kerapatan spora dan intensitas penyakit pada masing-masing waktu aplikasi dapat dilihat pada Gambar 2.

Gambar 2 menunjukkan bahwa intensitas penyakit paling rendah terdapat pada kerapatan spora terendah dan intensitas penyakit paling tinggi terdapat pada kerapatan spora tertinggi. Semakin tinggi tingkat

\footnotetext{
Gambar 2. Pengaruh kerapatan spora dan waktu aplikasi terhadap intensitas penyakit karat pada gulma teki 19 hari setelah inokulasi
} 
Tabel 1. Koefisien regresi (b) pada peubah jumlah pustul yang terbentuk dan intensitas penyakit

\begin{tabular}{lcccc}
\hline \multirow{2}{*}{\multicolumn{1}{c}{ Peubah }} & Pagi & Sore & t-hit. & t-0.05 \\
\cline { 2 - 5 } & $0,43 \times 10^{-3}$ & $2,84 \times 10^{-3}$ & 4,77 & $2,04 \mathrm{~S}$ \\
Jumlah Pustul & $0,00062 \times 10^{-3}$ & $0,0022 \times 10^{-3}$ & 3,04 & $2,04 \mathrm{~S}$ \\
\hline Intensitas Penyakit & \multicolumn{4}{c}{} \\
\hline
\end{tabular}

$\mathrm{S}=$ Berbeda nyata pada taraf $5 \%$

kerapatan spora maka intensitas penyakit juga semakin tinggi. Nilai b (koefisien regresi) pada inokulasi sore hari lebih besar dibandingkan nilai b waktu inokulasi pagi hari (Tabel 1) yang menunjukkan bahwa intensitas penyakit pada waktu inokulasi sore hari lebih tinggi dibandingkan intensitas penyakit pada waktu inokulasi pagi hari.

Intensitas penyakit yang dihasilkan ketika inokulasi yang dilakukan sore hari lebih tinggi dibadingkan dengan intensitas penyakit yang dihasilkan pada waktu inokulasi pagi hari. Intensitas penyakit pada kerapatan terendah yang diinokulasikan sore hari lebih tinggi dibandingkan dengan intensitas penyakit pada kerapatan tertinggi yang diinokulasikan pada pagi hari. Hal ini mungkin disebabkan oleh faktor lingkungan yaitu suhu (suhu setelah inokulasi). Inokulasi yang dilakukan pada pagi hari menyebabkan spora terekspos (terpapar) pada suhu tinggi (pada siang hari), dimana pada keadaaan suhu tinggi tersebut kecil sekali kemungkinan bagi urediniospora yang kontak dengan gulma teki dapat berkecambah dengan baik untuk selanjutnya membentuk pasak penetrasi, apalagi melakukan penetrasi ke dalam jaringan daun gulma teki. Hal ini sesuai dengan pendapat Semangun (1991) yang melaporkan bahwa suhu optimum untuk pertumbuhan dan perkembangan urediniospora jamur karat pada tanaman kedelai adalah sekitar $18-24^{\circ} \mathrm{C}$. Urediniospora tidak dapat berkecambah pada suhu di bawah $0^{\circ} \mathrm{C}$ dan suhu di atas $40^{\circ} \mathrm{C}$. Hasan \& Wapshere (1973) melaporkan kisaran suhu untuk perkecambahan dari urediniospora jamur karat $P$. chondrillina yang menyerang gulma skeleton adalah $0-36^{\circ} \mathrm{C}$, dengan suhu optimum $18^{\circ} \mathrm{C}$, dan urediniospora tidak dapat berkecambah pada suhu tinggi $\left(40^{\circ} \mathrm{C}\right)$. Sebaliknya inokulasi yang dilakukan sore hari, suhu setelah inokulasi cukup rendah (pada malam hari) dan urediniospora akan dihadapkan pada suhu yang cukup mendukung untuk perkecambahannya. Pada suhu yang rendah, urediniospora yang kontak dengan gulma teki akan lebih cepat dan banyak yang berkecambah dan dapat meningkatkan infektifitasnya (virulensinya). Dengan meningkatnya virulensinya maka jumlah pustul yang terbentuk juga semakin banyak akibatnya berat pustul juga semakin tinggi sehingga intensitas penyakit yang dihasilkan juga tinggi. Oleh karena itu, bila spora berada pada suhu rendah (optimum) maka akan meningkatkan virulensinya dan pada gilirannya intensitas penyakit yang ter jadi juga tinggi walapun gulma teki dalam keadaan pertumbuhan optimum. Hal ini didukung oleh Agrios (1988) yang menyatakan bahwa patogen akan menjadi sangat aktif bila mencapai suhu optimum, walapun inang juga dalam keadaan pertumbuhan optimum, tetapi inang tidak dapat menyaingi perkembangan patogen.

Pada Gambar 3 terlihat bahwa perkembangan penyakit pada waktu inokulasi sore hari lebih cepat dibandingkan dengan waktu inokulasi pagi hari. Perkembangan penyakit pada pengamatan pertama (hari ke-7) ke pengamatan kedua (hari ke-10) peningkatannya cepat, tetapi pada pengamatan selanjutnya berkurang dan semakin berkurang sampai tidak ter jadi perkembangan penyakit.

Kerapatan spora, waktu aplikasi dan interaksi antara keduanya berpengaruh nyata terhadap perkembangan penyakit. Umumnya semua patogen akan lebih cepat berkembang pada keadaan suhu optimum. Keadaan suhu di bawah atau di atas suhu optimum bagi perkembangan patogen atau di dekat suhu optimum bagi perkembangan inang maka perkembangan penyakit lambat, tetapi bila suhu mendekati optimum bagi patogen maka penyakit berkembang lebih cepat (Agrios, 1988). Hasil penelitian menunjukkan bahwa perkembangan penyakit semakin cepat dengan semaikin meningkatnya kerapatan spora. Perkembangan penyakit pada inokulasi sore hari lebih cepat dibandingkan dengan perkembangan penyakit pada inokulasi pagi hari pada semua tingkat kerapatan spora. Pada pengamatan pertama menunjukkan bahwa jumlah pustul yang terbentuk pada inokulasi sore hari lebih banyak dibandingkan dengan inokulasi yang dilakukan pagi hari, begitu juga dengan pengamatan hari berikutnya. Pada inokulasi sore hari ter jadi pertambahan jumlah pustul 
30.000

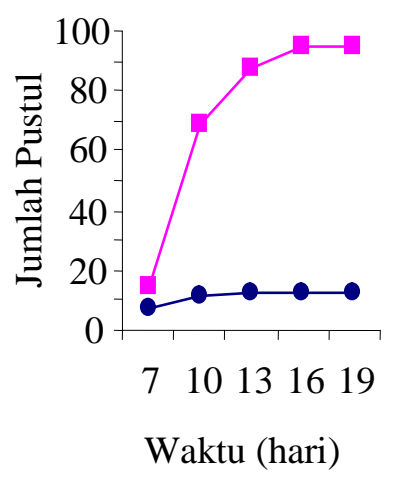

20.000

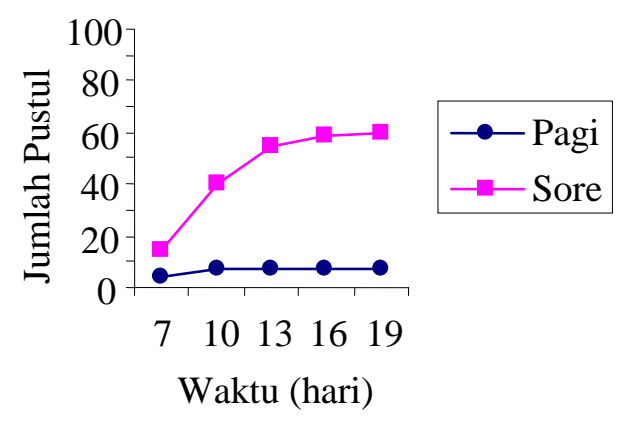

10.000

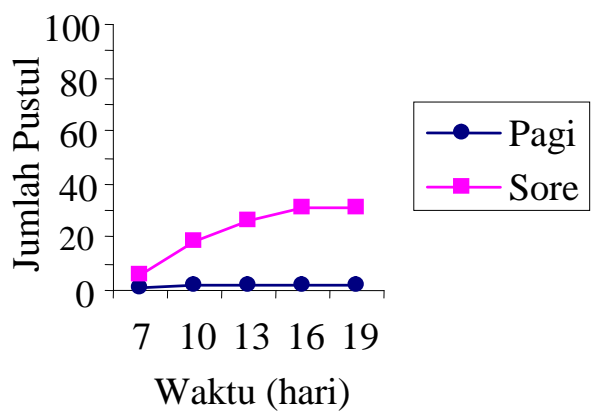

25.000

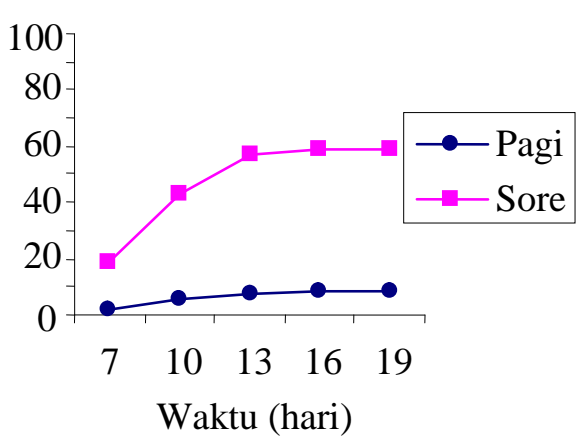

15.000

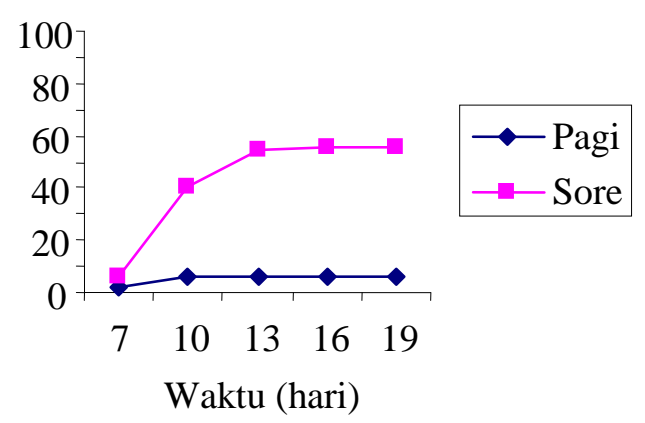

5000

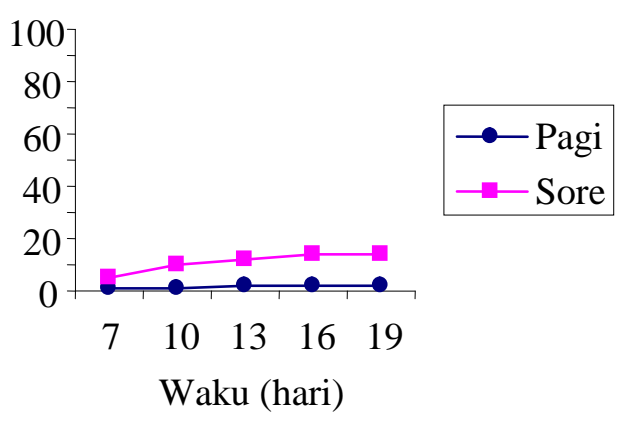

Gambar 3. Pengaruh kerapatan spora (5000 s.d 30.000 spora/ml larutan) dan waktu aplikasi (pagi atau sore) terhadap perkembangan penyakit karat Puccinia philippinensis pada gulma teki pada berbagai tingkat kerapatan spora. 
yang cukup banyak, namun pada inokulasi pagi hari hanya ter jadi penambahan jumlah pustul yang sedikit (1-2 pustul) bahkan tidak ter jadi pertambahan jumlah pustul sama sekali. Pada pengamatan hari selanjutnya baik inokulasi yang dilakukan sore hari maupun pagi hari pertambahan jumlah pustul semakin berkurang dan bahkan tidak ter jadi penambahan. Pada gambar 3 terlihat bahwa perkembangan penyakit yang ter jadi pada semua tingkat kerapatan spora yang diinokulasikan pada waktu sore hari menunjukkan perkembangan yang jauh lebih cepat dibandingkan dengan yang diinokulasikan pada pagi hari. Dengan demikian mungkin yang membedakan cepat lambatnya perkembangan penyakit adalah faktor suhu dan kelembaban udara. Kisaran suhu untuk perkecambahan spora jamur karat ini adalah 15 $30^{\circ} \mathrm{C}$ dan perkecambahan urediniospora terbanyak pada suhu rendah $\left(15^{\circ} \mathrm{C}\right)$. 0leh karena itu dengan semakin meningkatnya tingkat kerapatan spora tidak menjamin akan mempercepat perkecambahan dan perkembangan penyakit kalau tidak didukung oleh faktor lingkungan terutama suhu dan kelembaban udara. Sastrahidayat (1989) menyatakan bahwa tersedianya inokulum patogen yang tinggi tidak selalu diikuti dengan meningkatnya perkembangan penyakit, selama kondisi inang dan lingkungan kurang mendukung, dan sebaliknya meningkatnya kepekaan inang dan kondisi lingkungan yang sesuai (suhu dan kelembaban udara) mampu memacu patogenisitas penyakit atau patogen untuk menyebabkan perkembangan penyakit meningkat sehingga ter jadi epidemi. Besarnya pengaruh suhu terhadap perkembangan penyakit yang ter jadi setelah infeksi tergantung interaksi antara inang dan patogen (Agrios, 1988). Murdan \& Fauzi (2007) melaporkan bahwa kisaran suhu untuk ter jadinya infeksi jamur $P$. phillipinensis pada gulma teki berkisar antara $15-30^{\circ} \mathrm{C}$ dan lama kelembaban tinggi berlangsung paling kurang selama 6 jam. Semakin lama durasi kelembaban tinggi tersebut maka perkembangan penyakit karat pada gulma teki semakin besar.

Hasil penelitian yang dilaporkan pada tulisan ini menunjukkan bahwa jamur karat $P$. philippinensis bersifat patogenik (dapat menimbulkan penyakit) pada gulma teki sehingga berpotensi diterapkan sebagai agen pengendali hayati gulma teki yang sangat sukar dikendalikan baik secara mekanik maupun kimiawi. Selain itu, jamur karat ini tidak mampu menginfeksi tanaman-tanaman budidaya penting seperti padi, jagung, kedelai, kacang tanah dan kacang hijau (Fauzi \&
Murdan, 2005). Selain itu, hasil observasi lapangan menunjukkan bahwa tidak ada tanaman budidaya yang terinfeksi jamur karat di sekitar tempat ter jadinya infeksi jamur karat pada gulma teki. Hal ini menunjukkan bahwa jamur karat ini mempunyai inang yang spesifik, sehingga aman diterapkan sebagai agen pengendali hayati gulma teki. Jika jamur karat ini diaplikasikan sebagai agen pengendali hayati gulma teki maka waktu aplikasi yang terbaik adalah pada sore hari.

\section{SIMPULAN}

Semakin tinggi kerapatan spora yang diaplikasikan pada gulma teki maka semakin tinggi jumlah pustul yang terbentuk, semaikin tinggi intensitas penyakit yang terjadi dan semakin cepat penyakit berkembang. Urediniospora yang diaplikasikan pada sore hari menghasilkan pustul yang lebih banyak, intensitas penyakit yang lebih tinggi dan perkembangan penyakit yang lebih cepat dibandingkan dengan urediniospora yang diaplikasikan pada pagi hari.

\section{DAFTAR PUSTAKA}

Agrios, G. N. 1988. Plant Pathology. Third Edition. Academic Press. Inc. San Diego. California.

Callaway, M.B., S.C. Phatak, \& H.D. Wells. 1985. Studies on alternate hosts of the rust Puccinia canaliculata, a potential biological control agent for nutsedges. Plant Disease 69: 924-925.

Campbe11, C. L. \& L. V. Madden. 1990. Introduction to Plant Disease Epidemiology. John Wiley and Sons. New York.

Charudattan, R. 1985. The use of natural and genetically altered strains of pathogens for weed control. In M. A. Hoy \& D. C. Herzog, (eds) : Biological Control in Agricultural IPM System. Academic Press, Inc. Orlando. Florida.

Evans, H. C. 1991. Biological Control of tropical grassy weeds. In Baker, F. W. G. \& P. J. Terry (Eds) : Tropical Grassy Weeds. CAB International. Wallingford. Oxon. UK. pp 52-72. 
Evans, H. C. 1995. Pathogen-weed relationship: the practice and problem of host range screening. Proceeding of the Eight International Symposium on Biological Control of Weeds. DSIR/CSIRO. Melbourne. pp 539-551.

Fauzi, M. T. \& Murdan. 2005. Indigenous Rust Fungus (Uredinales) Attacking Purple Nutsedge (Cyperus rotundus) in Lombok Island. A paper presented at International Congress on Crop Security (ICCS 2005), University of Brawi jaya, Malang.

Fauzi, M. T., S. W. Adkins, P. J. Dart, H. J. Ogle, \& A. J. Tomley. 1996. Effect of temperature and leafwetness on infectivity of Puccinia abrupta var. partheniicola, a potensial biological control agent of parthenium weed. Proceedings of the Eleventh Australian Weeds Confernce, Weed Science Society of Victoria Inc., Melbourne.

Fauzi, M.T., A.J Tomley, P.J. Dart, H. J. Ogle, \& S.W. Adkins. 1999. The rust Puccinia abrupta var. partheniicola, a potential biological control agent of parthenium weed: Enviromental requirements for disease progress. Biological Control 14: 141145.

Hasan, S. \& A.J. Wapshere. 1973. The biology of Puccunia chondrillina a potensial biological control agent of skeleton weed. CSIRO, (c/o Station de recherches cytophatologi. France).

Konstermans, A.J.G., H. S. Wirjahardja, \& R. J. Dekker. 1987. The weeds: description, ecology and control. In M. Soerjani, A.J.G.H. Konstermans, \& G. Tjitrosoepomo (eds): Weed of Rice in Indonesia. Balai Pustaka. Jakarta. Indonesia. pp $24-565$.

Murdan \& M.T. Fauzi. 2007. Pengaruh suhu dan kelembaban terhadap terhadap infektivitas dan perkembangan penyakit yang disebabkan oleh jamur karat Puccinia sp., jamur potensial pengendali hayati gulma teki (Cyperus rotundus L.). Oryza VI (3): 243-252.
Nutman, F.J. \& F.M. Roberts. 1963. Studies on the biology of Hemileia vastratrix Bek \& BR. Coffee Berry Disease and Leaf Rust Research Unit. Department of Agriculture. Kenya.

Phatak, S.C., D.R. Sumner, H.D. Well, D.K. Bells, \& N.C. Glaze. 1983. Biological control of yellow nutsedge with the indigenous rust fungus Puccinia canaliculata. Science 219: 1446 - 1447.

Pons, T.L., J.H.H. Eussen, \& I.H. Utomi, 1987. Ecology of weed of rice. In M. Soejani, A.J.G.H. Konstermans, \& G. Tjitrosoepomo, (eds): Weed of Rice in Indonesia. Balai Pustaka. Jakarat. Indonesia. pp $15-23$.

Sastrahidayat, I.R. 1989. Ilmu Penyakit Tumbuhan. Usaha Nasional. Surabaya.

Semangun, H., 1991. Penyakit-penyakit Tanaman Pangan di Indonesia. Gadjah Mada University Press. Yogyakarta.

Sirjusingh, C., J.C. Sutton, \& M.J. Tsujita. 1996. Effect of inoculum concentration and host age on infection of geranium by Botrytis cenerea. Plant Disease 80 : 154-159.

Steel, R.G.D. \& J.H. Torrie. 1981. Principles and Procedures of Statistics: a Biometrical Approach, $2^{\text {nd }}$ edition. McGraw-Hill, Inc. Sydney.

TeBeest, D.O., X.B. Yang, \& C.R. Cisar. 1992. The status of biological control of weed with fungal pathogens. Annual Review of Phytophatology 30: 637-657.

Watson, A.K. 1991. The classical approach with plant pathogens. In D.O. TeBeest (ed): Microbial Control of Weeds. Routledge. Chapman and Hall Inc. New York. 